\title{
Decreased Basal, Noninsulin-Stimulated Glucose Uptake and Metabolism by Skeletal Soleus Muscle Isolated from Obese-Hyperglycemic (ob/ob) Mice
}

\author{
Guy S. Cuendet, Ernest G. Loten, Bernard Jeanrenaud, and Albert E. Renold \\ From the Institut de Biochimie Clinique and Laboratoires de Recherches Médicales, \\ University of Geneva Medical School, Geneva, Switzerland
}

A B S T RACT Insulin resistance of diaphragms of ob/ob mice has been repeatedly demonstrated previously both in vitro and in vivo. In the present study, transport and metabolism of glucose with and without insulin stimulation were compared in a skeletal muscle more likely than diaphragm or heart to be representative of the overall striated muscle mass, i.e. isolated soleus muscle. Compared with soleus muscle from lean controls, unstimulated lactate release in the presence of exogenous glucose was depressed from 16.2 to $12.3 \mathrm{nmol} / 60 \mathrm{~min}$ per $\mathrm{mg}$ wet wt in soleus from ob/ob mutants; glycolysis wass decreased from 6.6 to 3.7 and $\left[{ }^{14} \mathrm{C}\right]$ glucose oxidation to ${ }^{14} \mathrm{CO}_{2}$ from 0.90 to $0.33 \mathrm{nmol}$ glucose $/ 60$ min per $\mathrm{mg}$ wet wt. Uptake of 2-deoxyglucose (2DOG), both with and without insulin, was very much less for soleus from $o b / o b$ than from lean mice, at 2-DOG concentrations ranging from 0.1 to $10 \mathrm{mM}$, and in mice of $6-15 \mathrm{wk}$. When 2-DOG concentration was $1 \mathrm{mM}$, its basal uptake was $0.53 \mathrm{nmol} / 30$ min per $\mathrm{mg}$ wet wt for soleus of $o b / o b$ as against 0.96 for soleus of lean mice. The absolute increment due to $1 \mathrm{mU} / \mathrm{ml}$ insulin was 0.49 in muscle of $o b / o b$ as against 1.21 in that of lean mice.

When the resistance to insulin action was decreased by pretreatment in vivo by either streptozotocin injection or fasting, the decreased basal 2-DOG uptake of subsequently isolated soleus muscle was not improved. Inhibition of endogenous oxidation of fatty acids by 2-bromostearate, while greatly increasing ${ }^{14} \mathrm{CO}_{2}$ production from $\left[{ }^{14} \mathrm{C}\right]$ glucose, did not affect basal $\left[5-{ }^{3} \mathrm{H}\right]$ glucose metabolism or 2-DOG uptake. It is suggested that transport and/or phosphorylation of glucose under basal, unstimulated conditions are depressed in soleus muscle of $o b / o b$ mice,

Received for publication 28 April 1975 and in revised form 28 July 1976. whether or not resistance to insulin and hyperinsulinemia are also present. Although the origin of the decreased basal glucose uptake remains unknown, it might be related to a similar decrease in basal glucose uptake by ventromedial hypothalamic cells, an event presumably resulting in a tendency to hyperphagia. Decreased basal glucose uptake by soleus muscle of ob/ob mice might explain the hyperglycemia, and hence partly the hyperinsulinemia and excessive fat deposition of those animals.

\section{INTRODUCTION}

Obese hyperglycemic mice (C.57Bl/6J-ob/ob) are characterized by obesity, hyperinsulinemia, and hyperglycemia. The conversion of glucose to lipids is greatly elevated in both liver and adipose tissue, rationally explaining the obesity. This increased lipogenesis is considered secondary to the elevated serum insulin levels $(1,2)$, while the process that leads to hyperinsulinemia remains unexplained.

Since muscle accounts for a large proportion of metabolically active tissues of the body, selective impairment of glucose disposal by muscle could contribute to the genesis of the hyperglycemia, and hence of the hyperinsulinemia of these mice. In support of this view, Genuth et al. have demonstrated an altered ability of diaphragm muscle to take up 2deoxyglucose in vitro (3), and previous work from this laboratory has shown that glycogen synthesis in diaphragm muscle of obese mice responds poorly to exogenously added insulin in vivo (4). Whether diaphragm muscle, rhythmically contracting throughout life, may be considered typical of skeletal muscle in metabolic terms is, however, questionable.

The purpose of the present study was to investigate the metabolism of glucose in vitro by a true 
skeletal muscle from lean and obese mice, and to study the response of this tissue to insulin. Special care was taken to distinguish between defective glucose uptake as such, and insulin responsiveness of the muscle. The isolated soleus muscle was chosen, since, as previously shown for the rat $(5,6)$, it is a skeletal muscle that can be prepared intact (i.e. without broken or cut fibres), that responds well to insulin, and that is thin enough to allow for rapid diffusion of metabolites and gases.

\section{METHODS}

Animals. Male obese $(\mathrm{C} 57 \mathrm{Bl} / 6 \mathrm{~J}-\mathrm{ob} / \mathrm{ob})$ mice and their lean controls $(\mathrm{C} 57 \mathrm{Bl} / 6 \mathrm{~J}-+/+)$ were purchased from The Jackson Laboratory, Bar Harbor, Me. They were fed ad libitum and maintained in a constant-temperature $\left(23^{\circ} \mathrm{C}\right)$ animal room, with a fixed 12-h artificial light cycle.

Mice were made insulin-deficient by intraperitoneal injection of $180 \mathrm{mg} / \mathrm{kg}$ streptozotocin, dissolved in $0.9 \%$ $\mathrm{NaCl}$ and acidified with $0.05 \mathrm{M}$ citric acid to $\mathrm{pH} 4$. Such mice were routinely fasted $24 \mathrm{~h}$ before streptozotocin treatment, and control mice received the same volume of saline acidified with citric acid (2). Unless mentioned otherwise, all mice were used at 8-9 wk of age, when the body weight of the lean animals was about $20-25 \mathrm{~g}$ and that of the obese, $35-45 \mathrm{~g}$, whether streptozotocin-treated or not.

Mice were treated with insulin while kept under pentobarbital anesthesia $(100 \mathrm{mg} / \mathrm{kg}$ body wt). They received three injections of the hormone into a tail vein. The first $(0.4 \mathrm{U} / \mathrm{kg}$ body wt) was given $70 \mathrm{~min}$, the second and third $(0.2 \mathrm{U} / \mathrm{kg}$ body wt) $40 \mathrm{~min}$ and $10 \mathrm{~min}$, respectively, before removal and subsequent incubation of soleus muscles. Such insulin treatment decreased blood sugar to values of $82.5 \pm 12.4 \mathrm{mg} / 100 \mathrm{ml}$ (saline-treated controls: $212.8 \pm 10.5 \mathrm{mg} / 100 \mathrm{ml}, n=6$ for both).

Incubation techniques. Soleus muscles of mice were exposed as previously described for rat soleus (5), fixed with threads ligated around both tendons, and then dissected free from the legs. They were weighed, rinsed with $0.9 \%$ saline, and attached on a stainless steel holder by the two threads. The muscles thus prepared were then placed in flat-bottomed glass tubes (inner diameter, $2 \mathrm{~cm}$ ) containing $1.5 \mathrm{ml}$ of Krebs-Ringer bicarbonate buffer with $2 \%$ defatted bovine serum albumin (7) and the additions specified for each experiment. Incubations were carried out at $37^{\circ} \mathrm{C}$ in a shaking incubator. After 5 min of gasing with $\mathrm{O}_{2}: \mathrm{CO}_{2}(95: 5 \mathrm{vol} / \mathrm{vol})$, the tubes were sealed with rubber stoppers. Incubations were preceded by one or two 15-min preincubations necessary to wash out endogenous insulin, unless otherwise stated. When insulin was tested, it was present during the second preincubation and the incubation periods.

Measurements. Oxidation of $\left[\mathrm{U}_{-}{ }^{14} \mathrm{C}\right]$ glucose, $\left[1-{ }^{14} \mathrm{C}\right]$ acetate, or $\left[1^{-14} \mathrm{C}\right]$ pyruvate was estimated by collecting ${ }^{14} \mathrm{CO}_{2}$ produced by these substrates. At the end of the incubation, strips of filter paper placed before the incubation in a hanging center well were moistened with $0.1 \mathrm{ml} 1 \mathrm{~N}$ $\mathrm{NaOH}$ and the incubation vessels placed in an ice-cold water bath for $3 \mathrm{~min}$. The vessels were then opened briefly to remove and transfer the soleus muscle on its holder to liquid nitrogen. After resealing, the incubation medium was acidified with $0.3 \mathrm{ml} 30 \%(\mathrm{wt} / \mathrm{vol}) \mathrm{per}$ chloric acid, and the $\mathrm{CO}_{2}$ thus liberated collected during 30 $\min$ at $37^{\circ} \mathrm{C}$. The filters were dried and assayed for radio- activity in a toluene-based scintillation mixture. The acidified medium was centrifuged in a bench centrifuge and a sample of the supernatant was neutralized with $\mathrm{KOH}$ and stored at $-20^{\circ} \mathrm{C}$ for subsequent measurement of lactate (8), pyruvate (9), and alanine (10). Pyruvate measurements were performed within $4 \mathrm{~h}$ after sample collections. Formation of glycogen from labeled glucose was estimated after hydrolysis of the muscle in $0.5 \mathrm{ml} 1 \mathrm{~N}$ $\mathrm{NaOH}$ at $70^{\circ} \mathrm{C}$. Carrier glycogen $(10 \mathrm{mg})$ was added to the hydrolysate and glycogen was precipitated at $-20^{\circ} \mathrm{C}$ for $1 \mathrm{~h}$ with $66 \%$ ethanol (4). The glycogen precipitate was washed twice with ethanol $(66 \%)$ and dissolved in $0.5 \mathrm{ml}$ water and its radioactivity was measured. Muscle protein was estimated by the method of Lowry et al. (11) and triglyceride by measuring glycerol fluorimetrically after hydrolysis (12). Incorporation of $\left[1-{ }^{-14} \mathrm{C}\right]$ acetate into total lipids was measured after extracting the tissue according to Dole and Meinertz (13); the upper heptane phase was washed five times with $0.02 \mathrm{~N} \mathrm{H}_{2} \mathrm{SO}_{4}$, and a sample containing the labeled lipids was dried and counted. The same extraction procedure was used when lipogenesis from ${ }^{3} \mathrm{H}_{2} \mathrm{O}$ was measured (1).

The uptake of 2-deoxyglucose by muscles was used as an index of the rate of glucose transport and phosphorylation (14). This glucose analogue is known to be transported by the same glucose carrier system as glucose, phosphorylated to 2-deoxyglucose-6-phosphate but not metabolized further. After incubation, the muscle was washed in cold $0.9 \% \mathrm{NaCl}$ for $2-5 \mathrm{~min}$ and dissolved in $0.5 \mathrm{ml} 1 \mathrm{~N}$ $\mathrm{NaOH}$, and the radioactivity of this solution measured in a Packard liquid scintillation spectrometer (Tricarb 3380, Packard Instrument Co., Inc., Downers Grove, Ill.). The accumulation of radioactivity within muscle of either normal or obese mice remained linear for at least $25 \mathrm{~min}$ or for $10 \mathrm{~min}$, with 1 or $10 \mathrm{mM} 2$-deoxyglucose, respectively.

Overall true utilization of glucose itself was estimated by measuring the rate of formation of ${ }^{3} \mathrm{H}_{2} \mathrm{O}$ from $\left[5^{3} \mathrm{H}\right]-$ glucose (15) and adding the ${ }^{3} \mathrm{H}$ incorporated into glycogen during the same interval, i.e. $60 \mathrm{~min}$. To reduce the background from ${ }^{3} \mathrm{H}_{2} \mathrm{O}$ in $\left[5-{ }^{3} \mathrm{H}\right]$ glucose, the preparation of the latter was lyophilized to dryness before each experiment. At the end of incubation, ${ }^{3} \mathrm{H}_{2} \mathrm{O}$ in the medium was separated from $\left[5-{ }^{3} \mathrm{H}\right]$ glucose by ion exchange chromatography (16): samples $(500 \mu \mathrm{l})$ of the incubation medium were applied to a $0.45 \times 4.2$-cm column of Dowex $1 \times 2(200-$ 400 mesh Dow Chemical Co., Midland, Mich.) in borate form, packed into a Pasteur pipette. Tritiated water was eluted with $2.5 \mathrm{ml}$ water, while labeled glucose was retained on the resin. The eluate was counted in $5 \mathrm{ml}$ Instagel (Packard Instrument Co.).

Pyruvate dehydrogenase was measured in muscle homogenates according to the method of Coore et al. (17). Pairs of soleus muscles were first incubated with $5 \mathrm{mM}$ glucose for $1 \mathrm{~h}$ and frozen in liquid nitrogen. They were homogenized, just before enzyme assay, in a glass homogenizer containing $10 \mathrm{vol}$ of phosphate buffer $(100 \mathrm{mM}$, pH 7.3), EDTA (5 mM), and reduced glutathione (1.5 $\mathrm{mg} / \mathrm{ml}$ ). After centrifugation at $500 \mathrm{~g}$ for $3 \mathrm{~min}$, the supernatant was used for the assay. Activity measured in such homogenates was termed initial activity (i.e. enzyme activity prevailing in the tissue). Total enzyme activity was measured after incubating the homogenate with a specific pyruvate dehydrogenase phosphate phosphatase to dephosphorylate and activate the enzyme completely (17).

All reagents were of analytical grade. Enzymes and coenzymes were a generous gift from Dr. F. H. Schmidt, Boehringer-Mannheim GmbH, Mannheim, Germany, and streptozotocin from Dr. W. E. Dulin, the Upjohn 
TABLE I

Wet Weight, Protein, and Triglyceride Content of Soleus Muscle from Lean and ob/ob Mice

\begin{tabular}{|c|c|c|c|}
\hline Measurement & Lean & $o b / o b$ mice & $P$ \\
\hline Wet wt, $m g$ & $\begin{array}{l}8.6 \pm 0.1 \\
(45)\end{array}$ & $\begin{array}{l}9.3 \pm 0.2 \\
(52)\end{array}$ & $<0.005$ \\
\hline $\begin{array}{l}\text { Protein content, } \\
\quad \% \text { wet wt }\end{array}$ & $\begin{array}{c}17.0 \pm 0.4 \\
(45)\end{array}$ & $\begin{array}{l}15.2 \pm 0.3 \\
(52)\end{array}$ & $<0.001$ \\
\hline $\begin{array}{l}\text { Triglyceride content, } \\
\text { nmol/mg wet wt }\end{array}$ & $\begin{array}{l}9.9 \pm 0.7 \\
(10)\end{array}$ & $\begin{array}{l}23.0 \pm 1.4 \\
(18)\end{array}$ & $<0.001$ \\
\hline
\end{tabular}

Mean values \pm SEM; the number of individual muscles analysed in each instance is given in parentheses.

Company, Kalamazoo, Mich. Radioactive substances were purchased from The Radiochemical Centre, Amersham, Bucks., U. K.

\section{RESULTS}

In Table I are presented the wet weights (tendons included), the protein, and the triglyceride contents of soleus muscles of $\mathrm{C} 57 \mathrm{Bl} / 6 \mathrm{~J}$ lean and $o b / o b$ mice. As may be seen, the means of these measurements differed significantly between the groups of mice, but the differences were small except for the triglyceride content which, in muscles of $o b / o b$ mice, was twice that in the muscles of their lean controls. This increased triglyceride content was not associated with increased adipose tissue contamination, already excluded by light microscopic examination after staining with Sudan III. Table II shows that lactate output by muscle of $o b / o b$ mice incubated in the presence of glucose was less than that of controls. However, the release of pyruvate and alanine, as well as incorporation of $\left[\mathrm{U}_{-}{ }^{14} \mathrm{C}\right]$ glucose into glycogen, were similar for the two groups. The lactateto-pyruvate molar ratios measured under these experimental conditions were 11.2 and 8.5 for muscle from lean and obese mice, respectively; they are well within the range expected for well-oxygenated muscle. Glycolysis estimated by incorporation of tritium, from $\left[5^{-3} \mathrm{H}\right]$ glucose, into water, was decreased by $44 \%$ in muscles from $o b / o b$ mice, while the lactate plus pyruvate release was decreased by $22 \%$ only. This discrepancy suggested that the radioactivity of the glycolytic intermediates was more diluted in the muscle from ob/ob mice than in controls, and explained partly the $63 \%$ decrease of $\left[{ }^{14} \mathrm{C}\right]$ glucose oxidation to ${ }^{14} \mathrm{CO}_{2}$ in these muscles. However, it was not sufficient to explain the marked decrease of glucose oxidation. Due to this, the rate of pyruvate decarboxylation and acetate oxidation were studied. The formation of ${ }^{14} \mathrm{CO}_{2}$ from $\left[1{ }^{14} \mathrm{C}\right]$ pyruvate was de- creased by $40 \%$, a decrease unexplainable by a decrease of total pyruvate dehydrogenase activity, nor by an interconversion from the active to the inactive form of the enzyme, as both initial and total activities of the enzyme were similar for soleus from lean and ob/ob mice (Table II). The decarboxylation rates of exogenous pyruvate $(2 \mathrm{mM})$ agreed with the measurement of the enzyme activity of the homogenate; they were high when compared to the glucose oxidation rates, and demonstrate that its inhibition can be overcome, at least partly, by increasing the substrate concentration. As illustrated in Fig. 1, the oxidation of $\left[1-{ }^{14} \mathrm{C}\right]$ acetate to ${ }^{14} \mathrm{CO}_{2}$ was, at all acetate concentrations tested, significantly smaller in soleus muscle of ob/ob than that of controls. Explanations for this decreased acetate oxidation could include

TABLE II

Some Characteristics of Intermediary Metabolism of Soleus Muscles from Lean and $\mathrm{ob} / \mathrm{ob}$ Mice

\begin{tabular}{|c|c|c|c|}
\hline Measurement & Lean mice & $o b / o b$ mice & $P$ \\
\hline \multicolumn{4}{|c|}{ nmol/mg wet wt/60 min } \\
\hline Lactate release & $\begin{array}{c}16.2 \pm 0.7 \\
(42)\end{array}$ & $\begin{array}{c}12.3 \pm 0.7 \\
(19)\end{array}$ & $<0.001$ \\
\hline Pyruvate release & $\begin{array}{c}1.46 \pm 0.07 \\
(42)\end{array}$ & $\begin{array}{c}1.45 \pm 0.06 \\
(19)\end{array}$ & NS \\
\hline Alanine release & $\begin{array}{c}0.84 \pm 0.03 \\
(36)\end{array}$ & $\begin{array}{l}0.86 \pm 0.07 \\
\quad(23)\end{array}$ & NS \\
\hline $\begin{array}{l}{\left[{ }^{14} \mathrm{C}\right] \text { Glucose to }} \\
{\left[{ }^{14} \mathrm{C}\right] \text { glycogen }}\end{array}$ & $\begin{array}{l}0.74 \pm 0.06 \\
\quad(51)\end{array}$ & $\begin{array}{l}0.64 \pm 0.07 \\
\quad(17)\end{array}$ & NS \\
\hline Glycolysis* & $\begin{array}{c}6.61 \pm 0.67 \\
(10)\end{array}$ & $\begin{array}{c}3.70 \pm 0.19 \\
(12)\end{array}$ & $<0.001$ \\
\hline $\begin{array}{l}{\left[{ }^{14} \mathrm{C}\right] \text { Glucose to }} \\
{ }^{14} \mathrm{CO}_{2}\end{array}$ & $\begin{array}{l}0.90 \pm 0.04 \\
\quad(67)\end{array}$ & $\begin{array}{l}0.33 \pm 0.02 \\
\quad(23)\end{array}$ & $<0.001$ \\
\hline $\begin{array}{l}{\left[1-{ }^{14} \mathrm{C}\right] \text { Pyruvate to }} \\
{ }^{14} \mathrm{CO}_{2}\end{array}$ & $\begin{array}{c}7.27 \pm 0.59 \\
(6)\end{array}$ & $\begin{array}{c}4.20 \pm 0.36 \\
(6)\end{array}$ & $<0.002$ \\
\hline
\end{tabular}

Pyruvate dehydrogenase activity, nmol acetyl-UI $\mathrm{mg}$ wet $w \mathrm{t} / 60 \mathrm{~min}$
Initial

$4.62 \pm 0.05$

(6)

Total
$12.32 \pm 0.58$

(6)
$4.80 \pm 0.41$
$(6)$

$12.46 \pm 0.76$

(6)
Incubations in vitro were carried out for $60 \mathrm{~min}$ in KrebsRinger bicarbonate buffer containing $5 \mathrm{mM}$ glucose $(0.5 \mu \mathrm{Ci}$ $\left[\mathrm{U}^{-14} \mathrm{C}\right]$ glucose $\left./ \mathrm{ml}, 1 \mu \mathrm{Ci}\left[5-{ }^{3} \mathrm{H}\right] \mathrm{glucose} / \mathrm{ml}\right)$ and $2 \%$ defatted albumin. Values are mean \pm SEM with the number of experiments in parentheses.

* Measured as ${ }^{3} \mathrm{H}$ incorporation into water. 
$15 \mathrm{mM}$ glucose, varying acetate

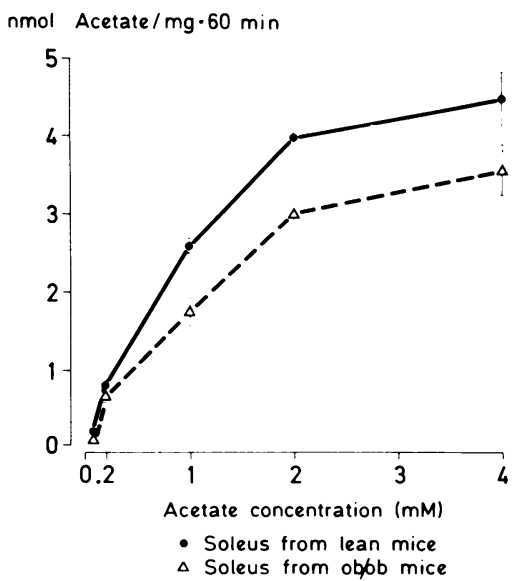

Figure $1 \quad\left[1-{ }^{14} \mathrm{C}\right]$ acetate oxidation to $\mathrm{CO}_{2}$ by soleus muscle from lean and $o b / o b$ mice. Incubations were carried out for $60 \mathrm{~min}$ in $1.5 \mathrm{ml}$ Krebs-Ringer bicarbonate containing $2 \%$ defatted albumin, $5 \mathrm{mM}$ glucose, and acetate as indicated. Values are mean $\pm \mathrm{SEM}$ of four or five experiments. $P$ was $<0.05$ at all acetate concentrations tested.

decreased activity of the enzyme system responsible for acetate activation and/or oxidation or dilution of labeled acetate in larger acetyl-coenzyme A pool. Attempt to differentiate between these possibilities was made by measuring the incorporation of labeled acetate $(2 \mathrm{mM})$ into lipids; the incorporation was more than $50 \%$ less for muscle from $o b / o b$ than from lean mice (controls: $48.3 \pm 8.2 ;$ ob/ob $22.01 \pm 2.9$, pmol acetate/mg wet wt per $60 \mathrm{~min} ; n=6$ for both). The discrepancy between the $25 \%$ decrement of acetate oxidation and the $50 \%$ decrease of acetate incorporation into lipids suggested either a lower specific activity of the acetyl-coenzyme $A$ in muscle from $o b / o b$ mice than from controls, or a decreased rate of the lipogenic activity in the muscle from obese mice. Lipogenesis was thus measured via incorporation of tritium, from tritiated water, into lipids, a process independent of specific activity of the acetylcoenzyme A pool. Lipogenic rates were similar in soleus muscle from ob/ob and lean mice, as shown in Table III. This suggested that the acetyl-coenzyme A pool was larger in muscles from ob/ob mouse than in controls. This hypothetical increase of acetyl-coenzyme A, a known inhibitor of pyruvate dehydrogenase activity $(18,19)$, may explain the decreased rate of pyruvate decarboxylation. The $63 \%$ decrease in [U- $\left.{ }^{14} \mathrm{C}\right]$ glucose oxidation observed in soleus muscle of $o b / o b$ mice can be the combined result of decrease of glycolysis, partial dilution of the labeled substrate, decreased pyruvate decarboxylation, and decreased acetate oxidation.

Although muscle of $o b / o b$ mice produced less lac- tate than controls in the presence of exogenous $5 \mathrm{mM}$ glucose (Table II), the reverse was true in the absence of glucose: lean mice $3.55 \pm 0.59$; ob/ob mice $5.27 \pm 0.47 \mathrm{nmol} / \mathrm{mg}$ wet wt per $60 \mathrm{~min}$, mean \pm SEM of 10 experiments. Since in the absence of exogenous glucose, lactate derives almost exclusively from muscle glycogen, glycogenolytic enzymes of muscles from $o b / o b$ mice incubated without glucose were sufficient to sustain greater than normal lactate output. Decreased lactate production in the presence of glucose was therefore more likely to result from decreased glucose transport and/or phosphorylation. The data summarized in Table IV are in keeping with this concept, since basal 2-deoxyglucose uptake was markedly diminished in muscles of $o b / o b$ mice when compared to controls, at all ages of animals tested. In the presence of a high concentration of insulin $(1 \mathrm{mU} / \mathrm{ml})$, the uptake of 2-deoxyglucose by muscle from 8-9-wk-old ob/ob mice increased only to values similar to those measured in muscle from lean mice in the absence of insulin.

In previous studies, lowering plasma insulin by streptozotocin treatment has been shown to reverse many of the metabolic abnormalities of liver and adipose tissue from $o b / o b$ mice $(1,2)$. To verify whether skeletal muscle metabolism of ob/ob mice could be similarly influenced, obese mice were treated with streptozotocin. After such treatment, their soleus muscles did not change in wet weight or protein content, but their triglyceride content fell to values $(14.95 \pm 0.75 \mathrm{nmol}$ triglycerides $/ \mathrm{mg}, n=6)$ intermediate between those of lean and untreated $o b / o b$ mice.

TABLE III

Incorporation of Tritium from ${ }^{3} \mathrm{H}_{2} \mathrm{O}$ into Lipids of Soleus Muscles from Lean and ob/ob Mice

\begin{tabular}{lcc}
\hline & \multicolumn{2}{c}{${ }^{3} \mathrm{H}$ incorporated into lipids } \\
\cline { 2 - 3 } Acetate & Lean mice & ob/ob mice \\
\hline$m M$ & \multicolumn{2}{c}{ natoms/mg wet $w t / 60)$ min } \\
0 & $1.94 \pm 0.10$ & $2.28 \pm 0.12$ \\
& $(7)$ & $(6)$ \\
0.1 & $2.16 \pm 0.30$ & $2.58 \pm 0.40$ \\
& $(6)$ & $(6)$ \\
1 & $2.75 \pm 0.27$ & $2.29 \pm 0.19$ \\
& $(10)$ & $(10)$ \\
4 & $2.79 \pm 0.55$ & $2.39 \pm 0.20$ \\
& $(5)$ & $(5)$
\end{tabular}

Conditions were as described in Fig. $1.1 \mathrm{mCi}{ }^{3} \mathrm{H}_{2} \mathrm{O} / \mathrm{ml}$ was present during the incubation period. Values are mean $\pm \mathrm{SEM}$ with number of experiments in parentheses. Controls vs. ob/ob $=$ NS. 
TABLE IV

2-Deoxyglucose Uptake in Soleus Muscles of Lean and ob/ob Mice of Different Ages

\begin{tabular}{|c|c|c|c|c|c|}
\hline \multirow[b]{2}{*}{ 2-Deoxyglucose } & \multirow[b]{2}{*}{ Addition } & \multirow[b]{2}{*}{ Age } & \multicolumn{2}{|c|}{ 2-Deoxyglucose uptake } & \multirow[b]{2}{*}{$P$} \\
\hline & & & Lean mice & ob/ob mice & \\
\hline$m M$ & & $w k$ & \multicolumn{2}{|c|}{ nmol/mg wet wt/30 $\mathrm{min}$} & \\
\hline 0.1 & None & $8-9$ & $\begin{array}{c}0.078 \pm 0.02 \\
\text { (11) }\end{array}$ & $\begin{array}{c}0.053 \pm 0.005 \\
(9)\end{array}$ & $<0.001$ \\
\hline 1 & None & $6-7$ & $\begin{array}{c}0.60 \pm 0.06 \\
(6)\end{array}$ & $\begin{array}{c}0.41 \pm 0.05 \\
(6)\end{array}$ & $<0.05$ \\
\hline 1 & None & $8-9$ & $\begin{array}{c}0.96 \pm 0.04 \\
(77)\end{array}$ & $\begin{array}{c}0.53 \pm 0.03 \\
(34)\end{array}$ & $<0.001$ \\
\hline 1 & Insulin & $8-9$ & $\begin{array}{c}2.17 \pm 0.08 \\
(30)\end{array}$ & $\begin{array}{c}1.02 \pm 0.08 \\
(15)\end{array}$ & $<0.001$ \\
\hline 10 & None & $8-9$ & $\begin{array}{c}6.52 \pm 0.53 \\
(5)\end{array}$ & $\begin{array}{c}3.99 \pm 0.27 \\
\quad(5)\end{array}$ & $<0.005$ \\
\hline 10 & None & 15 & $\begin{array}{c}7.25 \pm 0.46 \\
(5)\end{array}$ & $\begin{array}{c}4.03 \pm 0.46 \\
(5)\end{array}$ & $<0.005$ \\
\hline
\end{tabular}

Incubations were carried out for $15 \mathrm{~min}(0.1$ and $1 \mathrm{mM}$ 2-deoxyglucose $)$ or $5 \mathrm{~min}$ ( $10 \mathrm{mM}$ 2-deoxyglucose) in Krebs-Ringer bicarbonate buffer with $2 \%$ defatted albumin, $2 \mathrm{mM}$ sodium pyruvate, and labeled 2-deoxyglucose $(0.5 \mu \mathrm{Ci} / \mathrm{ml})$ as indicated, after two preincubations without 2-deoxyglucose. Insulin: $1 \mathrm{mU} / \mathrm{ml}$. Values $\pm S E M$, with the number of experiments in parentheses.

Fig. 2 illustrates the relation between insulin dose and 2-deoxyglucose uptake by soleus muscle removed from lean, $o b / o b$, and streptozotocin-treated ob/ob mice when plasma immunoreactive insulin levels of the donor animals were $30.0 \pm 2.5,550 \pm 50$, and $40.0 \pm 7.5 \mu \mathrm{U} / \mathrm{ml}$, respectively. Basal 2-deoxyglucose uptake by muscle from $o b / o b$ mice was decreased both for the untreated and the streptozotocin-treated
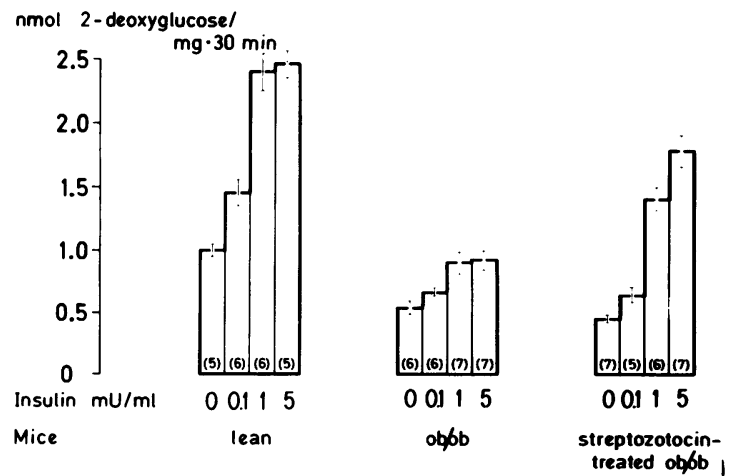

FIGURE 2 Basal and insulin stimulated uptake of labeled 2-deoxyglucose $(1 \mathrm{mM})$ by soleus muscle of lean, ob/ob, and streptozotocin-treated $o b / o b$ mice. Conditions were as described in Table IV. Values are means \pm SEM with the number of experiments in parentheses. groups. On the other hand, while the response to insulin in muscles of $o b / o b$ mice decreased at all insulin concentrations tested, it improved after streptozotocin-treatment. Indeed, the incremental 2-deoxyglucose uptake due to $5 \mathrm{mU}$ insulin/ml was the same for muscle obtained from lean and from streptozotocin-treated $o b / o b$ mice. It is interesting to note that streptozotocin treatment of lean mice did not alter basal 2-deoxyglucose uptake, but produced some increase in response of soleus muscle to insulin (Fig. 3).

The incorporation of tritium from $\left[5-{ }^{3} \mathrm{H}\right]$ glucose into glycogen by muscle from both lean and $o b / o b$ mice is shown in Fig. 4. Muscle of $o b / o b$ mice responded poorly to added insulin. Again, streptozotocin treatment of the ob/ob animals greatly improved the insulin effect upon subsequently isolated muscle.

Another approach used to lower the plasma insulin level of $o b / o b$ mice was prolonged fasting. After 8 days of fasting, plasma insulin of the $o b / o b$ mice fell from 400 to $22.5 \mu \mathrm{U}-\mathrm{ml}(20)$. When the soleus of such fasted mice was incubated under basal conditions, lactate output and $\left[{ }^{14} \mathrm{C}\right]$ glucose oxidation to ${ }^{14} \mathrm{CO}_{2}$ were $13.8 \pm 0.9$ and $0.17 \pm 0.02 \mathrm{nmol} / 60 \mathrm{~min}$ per mg wet wt, respectively, and were thus comparable 
to the values obtained in muscle from fed ob/ob mice (for comparison, see Table II). As shown in Table V, basal uptake of 2-deoxyglucose by muscle obtained from similarly fasted $o b / o b$ mice remained decreased when compared to that of muscle from fed lean mice. However, their response to insulin was quite marked (Table V).

Although uptake and phosphorylation of 2-deoxyglucose provides a widely accepted estimate of the uptake and phosphorylation of glucose itself, it was considered most desirable to measure the uptake of glucose more directly as well. Accordingly, glucose uptake was also derived from measurement of the incorporation of ${ }^{3} \mathrm{H}$ into glycogen and water from $\left[5^{-3} \mathrm{H}\right]$ glucose (15). As illustrated by Table VI, "total" basal $\left[5-{ }^{3} \mathrm{H}\right]$ glucose uptake measured more directly by this procedure was again smaller, $45 \%$ less for muscle of 9-wk-old ob/ob mice than for muscle from the same:age controls. Furthermore, the response to insulin again was less in the ob/ob than in the control muscle. Muscle from 6-wk-old ob/ob mice, barely obese and with only moderately elevated insulin levels $(3,21,22)$, still exhibited a decreased basal glucose uptake (70\% of the non-ob/ob value) whereas the magnitude of the response to insulin was almost normal (Table VI).

In vitro abnormalities of glucose oxidation and

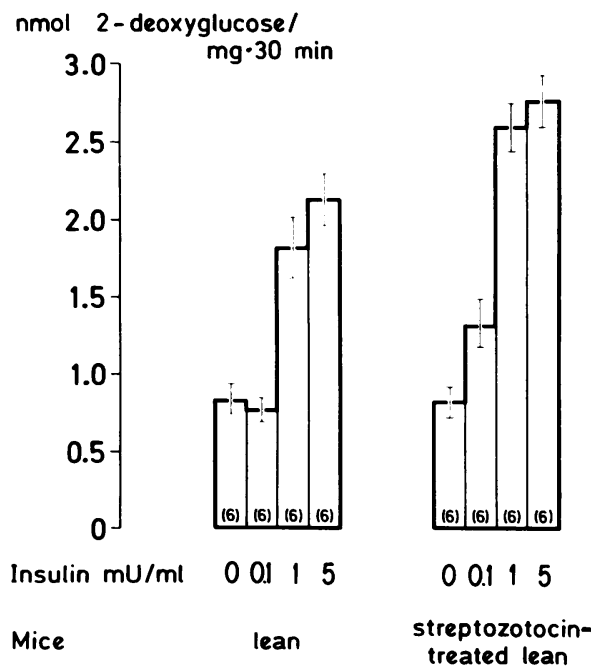

FIGURE 3 Basal and insulin stimulated uptake of labeled 2-deoxyglucose (1 $\mathrm{mM})$ by soleus muscle of lean and streptozotocin-treated mice. Experimental conditions were as described in Table IV. The streptozotocin-treated mice lost body weight over 8 days while their untreated controls gained weight (final body weights: $16.9 \pm 4$ and $20.9 \pm 2 \mathrm{~g}$, respectively). Plasma glucose was $639.0 \pm 20.0$ compared with $165.0 \pm 3.0 \mathrm{mg} / 100 \mathrm{ml}$ in the controls. The soleus muscles weighed $5.6 \pm 0.2 \mathrm{mg}$ in streptozotocin-treated mice as compared to $9.1 \pm 0.2$ in the untreated ones. The values shown are means \pm SEM, with the number of experiments in parentheses.

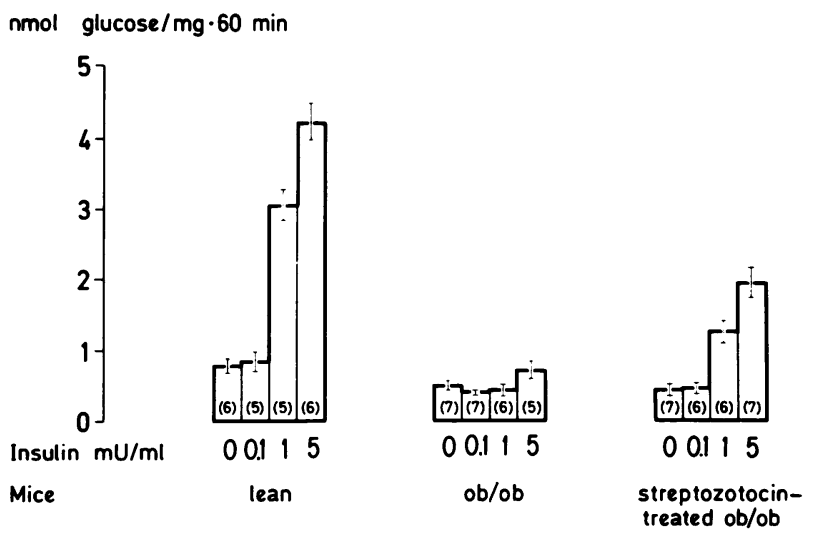

FIGURE 4 Effect of insulin on the incorporation of tritium from $\left[5-{ }^{3} \mathrm{H}\right]$ glucose into glycogen by soleus muscle of 9-10-wk-old lean, $o b / o b$ and streptozotocin-ob/ob mice. Incubation was $5 \mathrm{mM}$ glucose and $1 \mu \mathrm{Ci}\left[5^{-3} \mathrm{H}\right]$ glucose $/ \mathrm{ml}$. Values are means $\pm S E M$ with the number of experiments in parentheses.

uptake have been demonstrated in hearts from insulin-deficient alloxan-diabetic rats $(23,24)$ and in diaphragm from fat-fed rats $(25,26)$. These changes were associated with high rates of utilization of endogenous fatty acids and could be reversed by inhibiting fatty acid oxidation with albumin-bound 2-bromostearate $(26,27)$. Since skeletal muscle of $o b / o b$ mice has more triglyceride than that of lean mice, some of the abnormalities of $o b / o b$ muscle metabolism might be secondary to a primarily greater utilization of their endogenous lipids. Accordingly, glucose metabolism of soleus muscle was measured in the presence of $4 \mathrm{mM}$ 2-bromostearate. As shown in Table VII, the decreased glucose oxidation to $\mathrm{CO}_{2}$ by $o b / o b$ muscle was returned to normal by 2-bromostearate, whereas glucose carbon incorporation into glycogen was decreased. Moreover, the decreased basal 2-deoxyglucose uptake by muscle of

TABLE V

2-Deoxyglucose Uptake in Soleus Muscle of Fed Lean and 8-Days-Fasted ob/ob Mice: Effect of Insulin

\begin{tabular}{lccc}
\hline & \multicolumn{3}{c}{ 2-Deoxyglucose uptake } \\
\cline { 2 - 4 } Addition & Fed lean mice & Fasted oblob mice & $P$ \\
\hline \multirow{4}{*}{ Nonel/mg wet $w t \cdot 30 \mathrm{~min}$} & \\
& $1.17 \pm 0.12$ & $0.72 \pm 0.07$ & $<0.005$ \\
Insulin & $(7)$ & $(6)$ & $<0.02$ \\
& $2.84 \pm 0.17$ & $2.04 \pm 0.21$ & \\
& $(7)$ & $(6)$ &
\end{tabular}

Experimental conditions were as described in Table IV. Insulin: $1 \mathrm{mU} / \mathrm{ml}$. 2-deoxyglucose: $1 \mathrm{mM}$. Values are mean $\pm \mathrm{SEM}$, with the number of experiments in parentheses. 
ob/ob mice remained decreased, as did the similarly decreased total glucose uptake derived from the incorporation of tritium from $\left[5-{ }^{3} \mathrm{H}\right]$ glucose into glycogen and water.

Residual insulin effect on glucose uptake and metabolism might affect the basal uptake and, in particular, stimulate the transport of glucose into the soleus muscle of lean mice. That the "resetting" of the glucose transport and metabolism after insulin exposure might necessitate a long time lag has been demonstrated with frog sartorius muscle (28), and in rat diaphragm (29). On the other hand, when a rat heart, after exposure to insulin, was perfused with insulinfree medium, the rate of glucose uptake returned to basal level as insulin was washed off (30).

To test whether residual effect of insulin could affect basal uptake of muscle, lean mice were treated with insulin in vivo before the removal of soleus muscles, control mice being injected with saline. Muscles were removed and incubated without any preincubation. As shown in Table VIII, prior treatment with insulin did not increase glycolysis, glucose incorporation into glycogen, or total glucose uptake. Analogously, soleus muscles were taken from lean insulin-treated mice, preincubated for $30 \mathrm{~min}$ in the presence of the hormone $(5 \mathrm{mU} / \mathrm{ml})$ and then in its absence for two periods of $15 \mathrm{~min}$, and finally incubated without insulin, and glucose metabolism was measured. Control muscles were similarly processed, but obtained from untreated controls and incubated without insulin. As shown in Table VIII, such pretreatment with insulin did not change muscle glucose metabolism when compared to control muscles not exposed to the hormone.

\section{DISCUSSION}

The principal contribution of the present study is establishing that basal, unstimulated glucose uptake by isolated soleus muscle of $\mathrm{C} 57 \mathrm{Bl} / 6 \mathrm{~J}-\mathrm{ob} / \mathrm{ob}$ mice is decreased when compared to that of lean $\mathrm{C} 57 \mathrm{Bl} / 6 \mathrm{~J}$ $+/+$ controls. Whereas many prior studies have established that insulin-stimulated glucose uptake or metabolism of muscle from the ob/ob mutation is decreased in vitro (31-35) and in vivo $(4,36)$, only Genuth et al. (3) have previously reported decreased basal 2-deoxyglucose uptake by hemidiaphragm of $o b / o b$ mice. Others have not reported the same finding and even Genuth et al., although reporting a decreased basal uptake by diaphragm muscle,

TABLE VI

Basal and Insulin-Stimulated $\left[5-{ }^{3} \mathrm{H}\right]$ Glucose Uptake and ${ }^{3} \mathrm{H}$ Incorporation into Glycogen and Water in Soleus Muscles of 6- and 9-wk-Old Lean and ob/ob Mice

\begin{tabular}{|c|c|c|c|c|c|c|c|}
\hline Mice & Age & Insulin & $n$ & $\begin{array}{l}{\left[{ }^{3} \mathrm{H}\right] \text { Glucose }} \\
\text { to glycogen }\end{array}$ & Glycolysis* & $\begin{array}{l}\text { Total glucose } \\
\text { uptake }\end{array}$ & $\begin{array}{c}P \text { for } \\
\text { glucose uptake, } \\
\text { lean vs. ob/ob) }\end{array}$ \\
\hline & $w k$ & $m(1 / m l$ & & & nmoll/mg wt $\cdot 60 \mathrm{mi}$ & & \\
\hline \multirow[t]{4}{*}{ Fed lean } & 6 & 0 & 13 & $0.25 \pm 0.01$ & $6.79 \pm 0.82$ & $7.04 \pm 0.81$ & \\
\hline & & 0.1 & 6 & $0.72 \pm 0.14$ & $10.55 \pm 1.07$ & $11.27 \pm 1.17$ & \\
\hline & & 1 & 5 & $2.91 \pm 0.34$ & $16.12 \pm 1.71$ & $19.03 \pm 2.15$ & \\
\hline & & 5 & 5 & $3.01 \pm 0.46$ & $18.35 \pm 1.32$ & $21.36 \pm 2.08$ & \\
\hline \multirow[t]{4}{*}{ Fed $o b / o b$} & 6 & 0 & 14 & $0.24 \pm 0.03$ & $4.68 \pm 0.25$ & $4.92 \pm 0.27$ & $P<0.02$ \\
\hline & & 0.1 & 6 & $0.20 \pm 0.03$ & $6.61 \pm 1.20$ & $6.81 \pm 1.22$ & $P<0.05$ \\
\hline & & 1 & 5 & $0.59 \pm 0.15$ & $12.24 \pm 1.68$ & $12.83 \pm 1.10$ & $P<0.2$ \\
\hline & & 5 & 6 & $1.52 \pm 0.10$ & $14.84 \pm 1.54$ & $16.36 \pm 1.52$ & $P<0.1$ \\
\hline \multirow[t]{4}{*}{ Fed lean } & 9 & 0 & 10 & $0.57 \pm 0.11$ & $6.61 \pm 0.67$ & $7.18 \pm 0.87$ & \\
\hline & & 0.1 & 12 & $0.66 \pm 0.09$ & $8.01 \pm 0.42$ & $8.67 \pm 0.46$ & \\
\hline & & 1 & 12 & $2.13 \pm 0.25$ & $16.71 \pm 0.72$ & $18.84 \pm 0.83$ & \\
\hline & & 5 & 11 & $2.40 \pm 0.30$ & $16.64 \pm 0.99$ & $19.04 \pm 0.85$ & \\
\hline \multirow[t]{4}{*}{ Fed $o b / o b$} & 9 & 0 & 12 & $0.27 \pm 0.04$ & $3.70 \pm 0.19$ & $3.97 \pm 0.19$ & $P<0.001$ \\
\hline & & 0.1 & 12 & $0.25 \pm 0.03$ & $4.21 \pm 0.35$ & $4.46 \pm 0.35$ & $P<0.001$ \\
\hline & & 1 & 12 & $0.37 \pm 0.05$ & $6.91 \pm 0.77$ & $7.28 \pm 0.79$ & $P<0.001$ \\
\hline & & 5 & 11 & $0.64 \pm 0.06$ & $9.90 \pm 0.47$ & $10.54 \pm 0.54$ & $P<0.001$ \\
\hline
\end{tabular}

Incubations were carried out for $60 \mathrm{~min}$ in $1.5 \mathrm{ml}$ of Krebs-Ringer bicarbonate buffer containing $2 \%$ defatted albumin and $5 \mathrm{mM}$ glucose with the addition of $1 \mu \mathrm{Ci} / \mathrm{ml}\left[5-{ }^{3} \mathrm{H}\right] \mathrm{glu}$ cose. Incubation was preceded by two preincubations. Values are means \pm SEM.

* Measured as ${ }^{3} \mathrm{H}$ incorporation into water. 


\section{TABLE VII}

Effect of 2-Bromostearate (4 mM) on Glucose Uptake or Metabolism by Soleus Muscles of Lean and $\mathrm{ob} / \mathrm{ob}$ Mice

\begin{tabular}{|c|c|c|c|c|c|}
\hline Measurements & 2-Bromostearate & $n$ & Lean mice & $o b / o b$ mice & $P$ \\
\hline & & \multicolumn{4}{|c|}{ nmol/mg wet wt $.60 \mathrm{~min}$} \\
\hline \multirow{2}{*}{$\begin{array}{l}{\left[{ }^{14} \mathrm{C}\right] \mathrm{Glucose} \text { oxidation }} \\
\text { to }{ }^{14} \mathrm{CO}_{2}\end{array}$} & 0 & 5 & $0.75 \pm 0.15$ & $0.38 \pm 0.01$ & 0.05 \\
\hline & + & 5 & $1.16 \pm 0.34$ & $1.03 \pm 0.14$ & NS \\
\hline \multirow{2}{*}{$\begin{array}{l}{\left[{ }^{14} \mathrm{C}\right] \text { Glucose incorporation }} \\
\text { into glycogen }\end{array}$} & 0 & 5 & $0.77 \pm 0.15$ & $1.00 \pm 0.10$ & NS \\
\hline & + & 5 & $0.86 \pm 0.16$ & $0.45 \pm 0.09$ & $<0.001$ \\
\hline \multirow[t]{2}{*}[2-{}^{-14}\mathrm{C}]{ Deoxyglucose uptake } & 0 & 6 & $1.18 \pm 0.07$ & $0.64 \pm 0.05$ & $<0.00$ \\
\hline & + & 5 & $1.18 \pm 0.05$ & $0.73 \pm 0.09$ & $<0.00$ \\
\hline \multirow{2}{*}{$\begin{array}{l}\text { Total glucose uptake } \\
\text { (glycolysis + glycogen } \\
\text { synthesis) }\end{array}$} & 0 & 10 & $6.10 \pm 0.48$ & $4.80 \pm 0.25$ & $<0.025$ \\
\hline & + & 10 & $6.70 \pm 0.48$ & $4.75 \pm 0.50$ & $<0.02$ \\
\hline
\end{tabular}

Conditions were as described in Tables II, IV, and VI, except that $4 \%$ bovine albumin was used. 2-bromo-stearate, $4 \mathrm{mM}$; [U-14 $\mathrm{C}$ ]glucose, $5 \mathrm{mM}$; labeled 2-deoxyglucose, $1 \mathrm{mM} ;\left[5-{ }^{-3} \mathrm{H}\right]$ glucose, $5 \mathrm{mM}$. Values are means \pm SEM.

evidently were principally interested in the decreased insulin response; indeed, since these authors did not discuss the decrease in basal uptake, it may be assumed that they considered it a consequence of the decreased response of 2-deoxyglucose uptake to insulin.

The conclusion that basal, unstimulated glucose uptake by soleus muscle of $o b / o b$ mice is decreased was derived from the following observations: decreased $\left[{ }^{14} \mathrm{C}\right]$ glucose oxidation to ${ }^{14} \mathrm{CO}_{2}$, decreased lactate output in the presence of exogenous glucose, decreased total uptake of $\left[5{ }^{3} \mathrm{H}\right]$ glucose (sum of both glycogen synthesis and glycolysis), and decreased 2deoxyglucose accumulation, all in the absence of insulin, and after two preincubations to remove whatever insulin might have been present in the tissue at death. The significance of the decreased lactate output by ob/ob muscle incubated with glucose is enhanced by the observation of normal or increased lactate production in the absence of added glucose, in accord with the hypothesis that only the contribution of exogenous glucose to the production of lactate is reduced in muscle of $o b / o b$ mice. All of these observations taken together convincingly suggest a defect at an early step of glucose handling, presumably at the level of its transmembrane transport and/or phosphorylation, a defect independent of the interaction of insulin with skeletal muscle.

Although decreased 2-deoxyglucose uptake in unstimulated muscle tissue from $o b / o b$ mice has been previously reported for diaphragm (3), the confirmation of this hitherto isolated finding, as well as the more complete description of other metabolic anomalies in a true skeletal muscle, provides some degree of assurance in transferring to the skeletal muscle mass as a whole a number of observations previously made in the rather specialized muscle tissue usually studied in vitro, i.e. diaphragm.

The major question to be dealt with in this discussion is whether the decreased basal, unstimulated glucose uptake by the soleus muscle isolated from $o b / o b$ mice is a primary, or at least a relatively early, or a clearly secondary, relatively late consequence of the genetic defect in ob/ob mice. The studies reported here have attempted to deal with four possible mechanisms that might have secondarily led to the decreased basal, unstimulated glucose uptake. The first of these would be a primarily increased pool of acetyl coenzyme A in muscle, resulting from the more rapid utilization of the increased amounts

\section{TABLE VIII}

Effect of in Vivo andlor in Vitro Insulin Preexposure upon Glucose Metabolism of Subsequently Incubated Soleus Muscle from Lean Mice

\begin{tabular}{|c|c|c|c|c|c|c|}
\hline \multirow{2}{*}{\multicolumn{2}{|c|}{$\begin{array}{c}\text { In vivo } \\
\text { insulin } \\
\text { treatment }\end{array}$}} & \multicolumn{2}{|c|}{ Preincubation } & \multirow[b]{2}{*}{$\begin{array}{l}{\left[{ }^{3} \mathrm{H}\right] \mathrm{Glucose}} \\
\text { to glycogen }\end{array}$} & \multirow[b]{2}{*}{ Glycolysis* } & \multirow{2}{*}{$\begin{array}{c}\text { Total } \\
\text { glucose } \\
\text { uptake } \\
(1+2)\end{array}$} \\
\hline & & $30 \mathrm{~min}$ & $\begin{array}{l}15 \min \\
\text { twice }\end{array}$ & & & \\
\hline & & & & nmol/mg we & $u t \cdot 60 \mathrm{~min}$ & \\
\hline \multirow[t]{2}{*}{ A. } & No & No & No & $2.1 \pm 0.4$ & $6.8 \pm 1.2$ & $8.9 \pm 1.2$ \\
\hline & Yes & No & No & $1.7 \pm 0.2$ & $7.6 \pm 1.1$ & $9.3 \pm 0.9$ \\
\hline \multirow[t]{2}{*}{ B. } & No & Yes & Yes & $0.6 \pm 0.1$ & $7.2 \pm 0.5$ & $7.8 \pm 0.5$ \\
\hline & Yes & $\begin{array}{c}\text { Yes } \\
\text { (with insulin) }\end{array}$ & Yes & $0.5 \pm 0.1$ & $7.3 \pm 0.2$ & $7.8 \pm 0.2$ \\
\hline
\end{tabular}

Incubations were carried out for $60 \mathrm{~min}$ in $1.5 \mathrm{ml}$ of Krebs-Ringer bicarbonate buffer containing $2 \%$ defatted albumin and $5 \mathrm{m.M}$ glucose $\left(1 \mu \mathrm{Ci} / \mathrm{ml}\left[5-{ }^{3} \mathrm{H}\right] \mathrm{glu}\right.$ cose). Incubations were preceded or not by three consecutive preincubations without or, when indicated, with insulin $(5 \mathrm{mU} / \mathrm{ml})$. In vivo insulin treatment is described in Methods. Values are means \pm SEM of six experiments.

* Measured as ${ }^{3} \mathrm{H}$ incorporation into water. 
of triglyceride stores in $o b / o b$ muscle (Table I) and perhaps also from the higher rate of glycogenolysis measured in the absence of glucose in vitro. However, the experiments with 2-bromostearate, a known inhibitor of oxidation of endogenous fatty acid, while suggesting that accelerated lipolysis and fatty acid oxidation might be responsible for at least part of the decrease in the production of ${ }^{14} \mathrm{CO}_{2}$ from $\left[{ }^{14} \mathrm{C}\right]$ glucose by soleus muscle of ob/ob mice (Table VII), also show complete lack of effect of 2-bromostearate upon the two best indices of diminished glucose uptake, i.e. 2-deoxyglucose uptake and total $\left[5^{-3} \mathrm{H}\right]$ glucose uptake (glycolysis plus incorporation into glycogen). The overall conclusion from these experiments is that dilution from increased metabolism of endogenous substrate may be involved in the apparent decrease in glucose metabolism beyond acetyl coenzyme A, but cannot account for a significant part of the decreased glucose uptake and metabolism down to the level of pyruvate or lactate.

The second mechanism that might have resulted secondarily in decreased basal, unstimulated glucose uptake by isolated muscle would be the consequence of the already well-known and fully established resistance of tissue from $o b / o b$ mice to insulin action. Indeed, the present study has established a marked decrease in the responsiveness to insulin of a true skeletal muscle from $o b / o b$ mice, thereby confirming the previous observations on diaphragm in vitro and in vivo. Insulin resistance has been shown by several authors to be related to the degree of hyperinsulinemia. Even though the precise reason for this relationship must remain hypothetical, it may nevertheless be reasonably related to changes in insulin binding to tissues, a process shown in several instances to vary inversely with the prevailing insulin concentration in plasma (37-39). Once insulin resistance is established, it might thus secondarily result in decreased basal, unstimulated glucose uptake and metabolism as well.

As expected from previous studies $(28,32,33,40)$, both hyperinsulinemia and resistance to insulin action could be abolished by either caloric restrictions, i.e. fasting (Table V), or pretreatment with a diabetogenic drug, i.e. streptozotocin (Fig. 2). Our results do differ, however, from those obtained by Batchelor et al. (35) with diaphragm and soleus muscle from streptozotocin-treated obese mice, since these authors did not find improved responsiveness to insulin after streptozotocin treatment. The most important observation made in the present study with regard to resistance to insulin action and basal, unstimulated glucose uptake by skeletal muscle from $o b / o b$ mice is that major improvement in insulin responsiveness was not associated with any increase toward normal of the decreased basal, unstimulated 2-deoxyglucose uptake. Accordingly, the present studies do not support the hypothesis that decreased basal glucose uptake by muscle from $o b / o b$ mice is the secondary result of altered insulin responsiveness of these tissues.

The third factor considered as a possible mediator of secondary decrease in basal, unstimulated glucose uptake by soleus muscle from ob/ob mice was hyperglycemia. To avoid any interference of endogenous and exogenous glucose, despite careful washing of the tissues, basal uptake of 2-deoxyglucose was selected as the best index of glucose uptake available. It is evident from the data reported in Fig. 3 that the hyperglycemia, considerably greater than in all $o b / o b$ animals, was without effect upon unstimulated 2-deoxyglucose uptake by soleus muscle, removed and studied 8 days after hyperglycemia had been induced. The study also serves to rule out any impairment of stimulated or unstimulated 2-deoxyglucose uptake as a direct effect of streptozotocin on skeleton muscle tissue.

The fourth factor to be considered in attempting to explain decreased basal glucose uptake in muscle from obese mice is that residual insulin might stimulate glucose metabolism more in muscles from lean than in those from $o b / o b$ mice, since the former are clearly more insulin sensitive. The observed decreased basal glucose metabolism in muscle from obese mice would thus be artefactual. This possibility could be ruled out by the observation that prior exposures of muscles from controls to insulin followed by their washing and incubation without hormone did not alter glucose metabolism (Table VIII).

At this point, it seems reasonable to conclude that the decrease in basal, unstimulated glucose uptake by a true skeletal muscle isolated from ob/ob mice cannot be explained as secondary to most known metabolic anomalies of this mutant, including decreased responsiveness to insulin of muscle. This is not to say that the primary nature of the basal decrease in muscle glucose uptake should be accepted as established. In fact, since the decreased basal muscle glucose uptake observed in 6-wk-old ob/ob mice was less marked than that for muscle obtained from 8-wk-old animals (Table VI), the secondary nature of the defect remains likely.

Defective basal glucose uptake of muscle tissue, whether primary or secondary in origin, and with the obvious reservation that findings made on diaphragm and soleus muscle should be extrapolated to the entire skeletal muscle mass only with great caution, may help explain some of the features of the obesity symdrome. One conceivable pathogenic sequence could be: decreased glucose uptake by muscle $\rightarrow$ hyperglycemia $\rightarrow$ hyperinsulinemia $\rightarrow$ insulin resistance (possibly greater for muscle than adipose tissue) 
$\rightarrow$ obesity. Decreased basal glucose uptake by muscle may thus precede decreased responsiveness of muscle to insulin in the sequence leading to hyperglycemia and obesity.

The studies of Coleman (41) have suggested that hyperphagia may result, in ob/ob mutants, from the absence of a normal satiety factor. This satiety factor appears to be a circulating one since it is transferred by parabiosis (41). The following question arises: Could a defective circulating satiety factor be somehow linked to decreased basal glucose uptake by muscle? Since glucose uptake and its control at the level of hypothalamic ventromedial cells may be comparable to that of insulin-sensitive tissues $(42-44)$, it is conceivable that the production of an abnormal satiety factor in the $o b / o b$ mice might result from a decreased glucose uptake in the ventromedial hypothalamus area in a way analogous to that just described for soleus muscle. That possibility has in fact been reported by Baile et al. (45) for $o b / o b$ mice.

\section{ACKNOWLEDGMENTS}

We are greatly indebted to Mrs. Barbara Brunner for devoted and skilled technical assistance.

This work was supported by grants No. 3.1060 .73 and 3.2180.73 of the Fonds National Suisse de la Recherche Scientifique, Berne, and the Fondation Education et Recherche, Basel, Switzerland.

\section{REFERENCES}

1. Assimacopoulos-Jeannet, F., A. Singh, Y. Le Marchand, E. G. Loten, and B. Jeanrenaud. 1974. Abnormalities in lipogenesis and triglyceride secretion by perfused livers of obese-hyperglycaemic (ob/ob) mice: relationship with hyperinsulinaemia. Diabetologia. 10: 155-162.

2. Loten, E. G., A. Rabinovitch, and B. Jeanrenaud. 1974. In vivo studies on lipogenesis in obese hyperglycaemic $(o b / o b)$ mice: possible role of hyperinsulinaemia. Diabetologia. 10: 45-52.

3. Genuth, S. M., R. J. Przybylski, and D. M. Rosenberg. 1971. Insulin resistance in genetically obese, hyperglycemic mice. Endocrinology. 88: 1230-1238.

4. Stauffacher, W., and A. E. Renold. 1969. Effect of insulin in vivo on diaphragm and adipose tissue of obese mice. Am. J. Physiol. 216: 98-105.

5. Chaudry, I. H., and M. K. Gould. 1969. Kinetics of glucose uptake in isolated soleus muscle. Biochim. Biophys. Acta. 177: 527-536.

6. Clausen, T., J. Gliemann, J. Vinten, and P. G. Kohn. 1970. Stimulating effect of hyperosmolarity on glucose transport in adipocytes and muscle cells. Biochem. Biophys. Acta 211: 233-243.

7. Chen, R. F. 1967. Removal of fatty acids from serum albumin by charcoal treatment. J. Biol. Chem. 242: $173-181$.

8. Passonneau, J. V. 1970. Lactät Bestimmung. Fluorimetrische Methode. In Methoden der Enzymatischen Analyse. 2nd edition. Verlag-Chemie, Weinheim, Germany. 1430-1433.

9. Passonneau, J. V., and O. H. Lowry. 1970. Pyruvät.
Fluorometrische Bestimmung. In Methoden der Enzymatischen Analyse. 2nd edition. Verlag-Chemie, Weinheim, Germany. 1412-1416.

10. Williamson, D. H. 1970. L-Alamin. Bestimmung mit Alanin-Dehydrogenase. In Methoden der Enzymatischen Analyse. 2nd edition. Verlag-Chemie, Weinheim, Germany. 1634-1635.

11. Lowry, O. H., N. J. Rosebrough, A. L. Farr, and R. J. Randall. 1951. Protein measurement with the Folin phenol reagent. J. Biol. Chem. 193: 265-275.

12. Le Marchand, Y., A. Singh, F. Assimacopoulos-Jeannet, L. Orci, C. Rouiller, and B. Jeanrenaud. 1973. A role of the microtubular system in the release of very low density lipoproteins by perfused mouse livers. J. Biol. Chem. 248: 6862-6870.

13. Dole, V. P., and M. Meinertz. 1960. Microdetermination of long-chain fatty acids in plasma and tissues. J. Biol. Chem. 235: 2595-2599.

14. Kipnis, D. M., and C. F. Cori. 1960. Studies of tissue permeability. VI. The penetration and phosphorylation of 2-deoxyglucose in the diaphragm of diabetic rats. J. Biol. Chem. 235: 3070-3075.

15. Ashcroft, S. J. H., L. C. C. Weerasinghe, J. M. Basset, and P. J. Randle. 1972. The pentose cycle and insulin release in mouse pancreatic islets. Biochem. J. 126: $525-532$

16. Hallén, A. 1960. Chromatographic analysis of sugars as complex borate ions. Acta Chem. Scand. 14: 22492250 .

17. Coore, H. G., R. M. Denton, B. R. Martin, and P. J. Randle. 1971. Regulation of adipose tissue pyruvate dehydrogenase by insulin and other hormones. Biochem. J. 125: 115-127.

18. Garland, P. B., and P. J. Randle. 1964. Control of pyruvate dehydrogenase in the perfused rat heart b! the intracellular concentration of acetyl-Coenzyme $\mathrm{A}$. Biochem. J. 91: 6C-7C.

19. Cooper, R. H., P. J. Randle, and R. M. Denton. 1974. Regulation of heart muscle pyruvate dehydrogenase kinase. Biochem. J. 143: 625-641.

20. Cuendet, G. S., E. G. Loten, D. P. Cameron, A. E. Renold, and E. B. Marliss. 1975. Hormone-substrate responses to total fasting in lean and obese mice. Am. J. Physiol. 228: 276-283.

21. Stauffacher, W., A. E. Lambert, D. Vecchio, and A. E. Renold. 1967. Measurements of insulin activities in pancreas and serum of mice with spontaneous ("obese" and "New Zealand obese") and induced (goldthioglucose) obesity and hyperglycemia, with considerations on the pathogenesis of the spontaneous syndrome. Diabetologia. 3: 230-237.

22. Westman, S. 1968. Development of the obese-hyperglycaemic syndrome in mice. Diabetologia. 4: 141149.

23. Garland, P. B., and P. J. Randle. 1964. Regulation of glucose uptake by muscle. 10. Effects of alloxin-diabetes, starvation, hypophysectomy and adrenalectomy, and of fatty acids, ketone bodies and pvruvate, on the glycerol output and concentrations of free fatty acids, long-chain fatty acyl-coenzyme $A$, glycerol phosphate and citrate-cycle intermediates in rat heart and diaphragm muscles. Biochem. J. 93: 678-687.

24. Randle, P. J., E. A. Newsholme, and P. B. Garland. 1964. Regulation of glucose uptake by muscle. 8. Effect of fatty acids, ketone bodies and pvruvate, and of alloxan-diabetes and starvation on the uptake and metabolic fate of glucose in rat heart and diaphragm muscles. Biochem. J. 93: 652-665. 
25. Blázquez, E., and C. Lopez Quijada. 1968. The effect of a high-fat diet on glucose, insulin sensitivity and plasma insulin in rats. J. Endocrinol. 42: 489-494.

26. Bringolf, M., N. Zaragoza, D. Rivier, and J.-P. Felber. 1972. Studies on the metabolic effects induced in the rat by a high-fat diet. Inhibition of pyruvate metabolism in diaphragm in vitro and its relation to the oxidation of fatty acids. Eur. J. Biochem. 26: 360-367.

27. Randle, P. J. 1969. Apparent reversal of insulin resistance in cardiac muscle in alloxan-diabetes by 2-bromostereate. Nature (Lond.). 221: 777.

28. Narahara, H. T., and P. Özand. 1963. Studies of tissue permeability. IX. The effect of insulin on the penetration of 3-methylglucose- $\mathrm{H}^{3}$ in frog muscle. J. Biol. Chem. 238: 40-49.

29. Stadies, W. C., N. Haugaard, and M. Vaughan. 1952. Studies of insulin binding with isotopically labeled insulin. J. Biol. Chem. 199: 729-739.

30. Bleehen, N. J., and R. B. Fischer. 1952. The action of insulin on the surviving rat's heart. J. Physiol. (Lond.). 118: 27P-28P.

31. Chlouverakis, C., and P. A. White. 1969. Obesity and insulin resistance in the obese-hyperglycemic mouse (ob ob). Metab. Clin. Exp. 18: 998-1006.

32. Mahler, R. M., and O. Szabo. 1971. Amelioration of insulin resistance in obese mice. Am. J. Physiol. 221: 980-983.

33. Abraham, R. R., and A. Beloff-Chain. 1971. Hormonal control of intermediary metabolism in obese-hyperglycemic mice. I. The sensitivity and response to insulin in adipose tissue and muscle in vitro. Diabetes. 20: $522-534$

34. Chlouverakis, C. 1972. Insulin resistance of parabiotic obese-hyperglycemic mice (ob/ob). Horm. Metab. Res. 4: 143-148.

35. Batchelor, B. R., J. S. Stern, P. R. Johnson, and R. J. Mahler. 1975. Effects of streptozotocin on glucose metabolism, insulin response, and adiposity in $o b / o b$ mice. Metab. Clin. Exp. 24: 77-91.
36. Stauffacher, W., L. Orci, D. P. Cameron, I. M. Burr, and A. E. Renold. 1971. Spontaneous hyperglycemia and/or obesity in laboratory rodents: an example of the possible usefulness of animal disease models with both genetic and environmental components. Recent Prog. Horm. Res. 27: 41-95.

37. Freychet, P., M. H. Laudat, P. Laudat, G. Rosselin, C. R. Kahn, P. Gordon, and J. Roth. 1972. Impairment of insulin binding to the fat cell membrane in the obese hyperglycemic mouse. FEBS (Fed. Eur. Biochem. Soc.) Lett. 25: 339-342.

38. Kahn, C. R., D. M. Neville, Jr., and J. Roth. 1973 Insulin-receptor interaction in the obese-hyperglycemic mouse. A model of insulin resistance. J. Biol. Chem. 248: 244-250.

39. Gavin, J. R., III, J. Roth, D. M. Neville, Jr., P. de Meyts, and D. N. Buell. 1974. Insulin-dependent regulation of insulin receptor concentrations: a direct demonstration in cell culture. Proc. Natl. Acad. Sci. U. S. A. 71: $84-88$

40. Batt, R., and P. Miahle. 1966. Insulin resistance of the inherently obese mouse-ob ob. Nature (Lond.). 212 289-290.

41. Coleman, D. L. 1973. Effect of parabiosis of obese with diabetes and normal mice. Diabetologia. 9. 294-298.

42. Debons, A. F., I. Krimsky, H. J. Likuski, A. From., and R. J. Cloutier. 1968. Goldthioglucose damage to the satiety center: inhibition in diabetes. Am. J. Physiol. 214: 652-658.

43. Debons, A. F., I. Krimsky, A. From., and R. J. Cloutier. 1969. Rapid effects of insulin on the hypothalamic satiety center. Am. J. Physiol. 217: 1114-1118.

44. Panksepp, J. 1974. Hypothalamic regulation of energy balance and feeding behavior. Fed. Proc. 33: 11501165.

45. Baile, C. A., M. G. Herrera, and J. Mayer. 1970. Ventromedial hypothalamus and hyperphagia in hyperglycemic obese mice. Am. J. Physiol. 218: 857-863. 